\title{
Re-Imaging African Nations as Preferred Foreign Direct Investment Destinations: Towards a Sustainable Nation Brand-Based Framework
}

\author{
Tafadzwa Matiza \\ Department of Business Management, University of Limpopo, Turfloop Campus, South Africa \\ Email: matizata@hotmail.com \\ Olabanji. A Oni \\ Department of Business Management, University of Limpopo, Turfloop Campus, South Africa \\ Email: olabanji.oni@ul.ac.za
}

\section{Doi:10.5901/mjss.2014.v5n9p663}

\begin{abstract}
This paper takes into account the image challenge faced by African nations in the attraction of foreign direct investment to their economies. As a potential panacea to this challenge, this paper posits a theoretical framework that establishes a relationship between nation brand theory and investment promotion practice to aid African nations in re-imaging themselves as investment destinations. The nation brand-based investment promotion model framework is a grand synthesis of concepts and ideas from the fields of nation branding and investment promotion. This paper serves as an introduction of the framework, particularly focusing on the concepts informing the model and the modalities of nation branding as an investment promotion approach. Critically, this paper describes the theoretical foundations for each phase of the framework and serves as the starting point for a more in-depth discussion in future studies of the framework as a potential methodology for investment promotion.
\end{abstract}

Keywords: Africa, foreign direct investment, investment promotion, image, nation branding

\section{Introduction}

The images of nations, much like those of corporate and product brands are susceptible to negative perceptions and stereotypes. As Fan (2009) points out the image of a nation is defined by its external audience, which is consumers, inward investors, foreign governments, the media, and external firms. Dinnie (2008) does suggest that the perceptions of people outside the country are influenced by personal experiences, the media and its coverage of issues pertaining to the nation, and stereotyping. It is this existing image or perception of a country that is referred to as a country's nation brand, with a nation brand being viewed as a representation of the enduring reputation of a specific country (Martin \& Eroglu, 1993, Bellosso, 2010).

The image of a country is in essence the picture, reputation or stereotype that is attached to a specific country, (Grundey, Tolub \& Brukiene, 2006). This reputation or stereotype is based on the cognitive (what one knows about a place); affective (how one feels about a certain place); evaluative (how one evaluates the place or its residents); and/or behavioural (whether one considers immigrating to/working in/visiting/investing in a certain place) processes of individuals, Boulding cited in (Avhraham \& Ketter, 2008). It follows then that individual nations have distinct images that are unique to their particular individual situations, as it is these images that 'consumers' of nation offerings use to make consumption related decisions. In the case of African nations such as Zimbabwe, Nigeria and more recently Egypt, the mention of their country in other parts of the world evokes negative images of civil unrest, war, poverty and disease (Annan cited in Odenthal \& Zimny, 1999). As a result most investors discount Africa as a location for investment because of the negative image the continent has as a region (Odenthal \& Zimny, 1999).

The (OECD, 2010:3) simplifies investment promotion as the process that "highlights profitable investment opportunities, by identifying local partners, and by providing a positive image of the economy." Investment promotion consists of, information provision to potential investors, the provision of services to potential investors and more pertinently, the creation of an attractive image of the country as an investment destination, (Wells \& Wint, 2000). Certainly country images have a significant influence on foreign direct investment decisions (Kalamova \& Konrad, 2009), with some proponents of nation branding believing that the movement of international capital is influenced by perceptions of investors of countries as brands (Partzalis \& Roderiguez, 2003, Duah, 2010). As Dinnie (2008) points out, in the case of 
nations associated with negative events, the 'stigma' associated with the nation impinges on the inflow of tourism, foreign aid and foreign direct investment, even long after these negative events have become irrelevant. To this end, Morisset (2001) concedes that while it takes time for a country to modify its image, nation branding seeks to address the gap between the perception that exists of a country and the image the country aspires to espouse in the minds of investors.

African nations have long been burdened with the image challenges of being located on the 'Dark Continent'. According to the United Nations (UN, 1995) Africa has long suffered from adverse media and academic exposure, identifying the major obstacle in investment promotion for African nations to be the negative attitude towards the continent as a whole, which they believe is fuelled by the lack of adequate and current information on African countries. This has invariably led to stereotyping of African nations.

\section{Theoretical Contribution of the Model}

The challenge of attracting FDI to African countries is well documented (UN, 1995, United Nations Industrial Development Organisation, UNIDO, 2011, Sichei \& Kinyondo, 2012), with the image of the continent and individual African nations posing as a significant barrier to FDI inflows. In an attempt to address this and a myriad of other challenges in investment attraction, African governments have established FDI-specific frameworks which have resulted in the establishment of investment promotion agencies (IPAs) and specialised investment promotion programs. By 1998, 45 of the 53 countries in Africa had established such agencies (Sichie \& Kinyondo, 2012). However, despite their best efforts IPAs in Africa have to a larger extent not been able to improve FDI inflows to their economies due to at times overbearing stereotypes that exist of Africa as a continent and its individual countries as investment destinations.

The NBBIPM is premised on the interventionist approach to investment promotion, (Trnik, 2007), which suggests that a suitable investment climate may not be sufficient for the effective attraction of FDI due to existing market failure as a result of perception or information gaps. It is this approach to attracting FDI that has resulted in the practice of modern marketing-related activities referred to as investment promotion by governments and quasi-government organisations. This paper posits the NBBIPM, a theoretical framework, as a strategic approach and potential panacea to the imagerelated challenges being faced by African nations in FDI attraction.

Sun (2009), notes that much of the work in the field of nation branding is limited to empirical investigations relating to the positioning and implementation of country-specific nation branding programs, while scholarly work in the field is primarily conceptual in nature. While modern investment promotion consists of three basic activities conducted by governments or investment promotion agencies (IPAs), namely, creating an attractive image of a country as an investment destination, information provision to potential and current investors and providing services to prospective investors (Matiza \& Oni, 2013, Trnik, 2007, Wells \& Wint, 2000). More pertinently Wells and Wint (2000) establish that nation-image building in investment promotion is subjective and mainly practise based, rooted in traditional marketing activities such as exhibitions, road shows and trade visits. There is a notable absence of a framework that bridges the fields of nation branding and investment promotion. To this end, in-order to fill the gap between investment promotion practice and nation branding theory, this paper attempts to contextualize the Nation Brand-Based Investment Promotion Model (NBBIPM) as the critical link between the theory of nation-image management, nation branding (Dinnie, 2008) and nation-image building practice in investment promotion (Wells \& Wint, 2000).

The NBBIPM is a grand synthesis of concepts and ideas in nation branding, investment promotion and traditional marketing and seeks to provide a theoretical blueprint for the re-imaging of nations. Such a model would benefit African IPAs in their attempts to re-image their countries as distinct and attractive foreign investment destinations and ultimately positively impact on the image of the continent of Africa as an investment destination. Perhaps the greatest potential contribution of this model is the development of a new methodology to investment promotion and potentially the basis for a new discourse in FDI-related nation image building practice.

\section{Theoretical Model: Nation Brand Based Investment Promotion Model (NBBIPM)}

The Nation Brand Based Investment Promotion Model (NBBIPM) is based on the findings of a broader research study conducted by Matiza and Oni (2013), into the potential utilisation of nation branding as an investment promotion approach for the Zimbabwean government (see Figure 1). This paper recognises that the generic model proposed for the Zimbabwean government has wider applications throughout the African continent. 
Figure 1. Nation Brand Based Investment Promotion Model (NBBIPM)
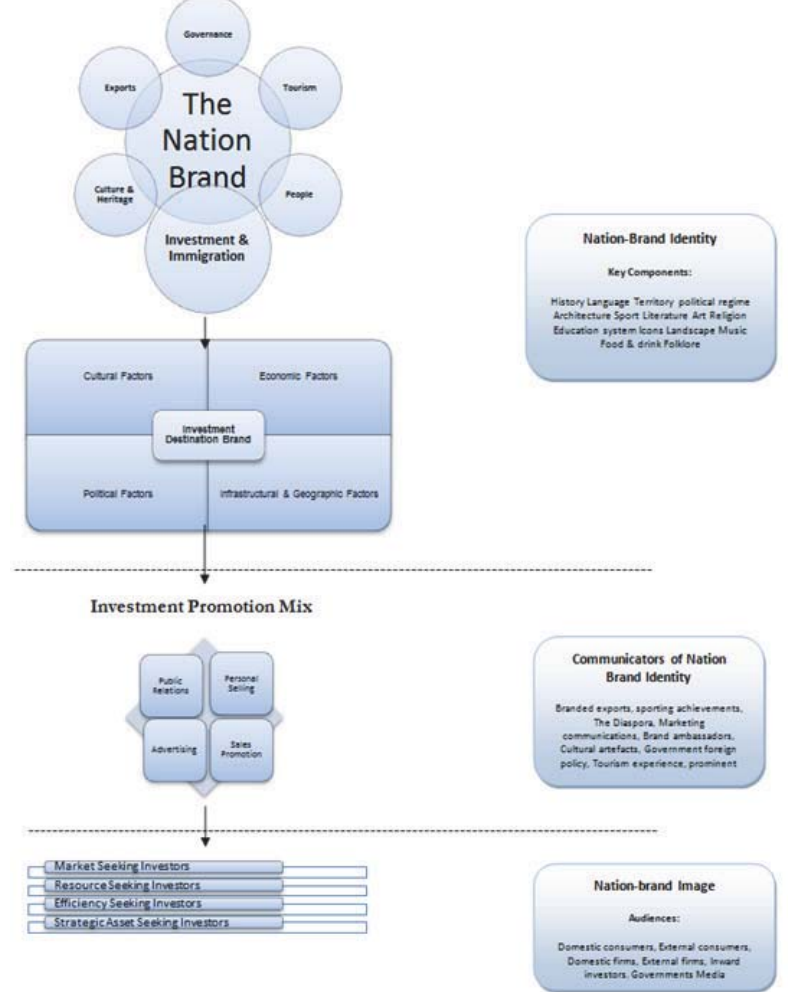

Source: Author's own construction. Based on models by: Anholt (2000), Dinnie (2008), Sun (2009) and Kaneva (2011)

\subsection{The Nation-Brand Identity And Image Conceptual Model}

The conceptual model of nation-brand identity and image, (Figure 2) illustrates the nation identity and image in the nationbrand context. According to Dinnie (2008) different nations selectively focus on distinct and appropriate components of the model, which facilitate their attainment of nation-brand specific objectives. He (Dinnie, 2008) uses the example of how a nation can benefit from a range of nation branded export products, such as German-made cars in the case of Germany, and Japanese-made electronics in the case of Japan. These countries can utilise their export product brands as a 'communicator' of a distinct nation brand identity.

Figure 3: Conceptual model of nation-brand identity and image

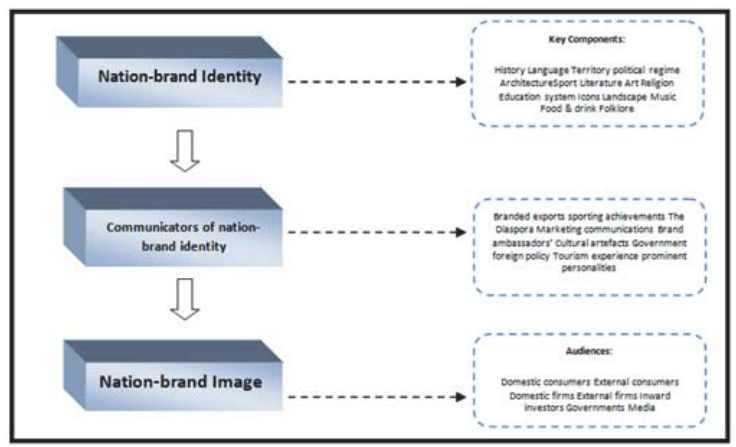

Source: Adapted from Dinnie (2008:49). 
The conceptual model of nation-brand identity and image outlines nation-brand identity and image as a three tier process, where there is an enduring nation identity, which is communicated through various mediums to specific target audiences. The premise of the model is that the nation-brand image is derived from the nation-brand identity through certain communicators such as branded exports and marketing communications. The audience is also diverse and these include inward investors and external firms. In the context of the NBBIPM, the conceptual model highlights the cognitive process of nation-brand image formation. This is where a nation uses key unique characteristics by which it is or rather wants to be identified by, and transmits this identity to its target audience through specific communicators. The final step is the target audience forming an image of that nation.

\subsection{Phase 1: Nation-Brand Identity}

The phase 1 is the creation of a nation-brand identity, and this would be in two steps, first is the creation and management of an overall nation brand by taking into account a nation's history, language, culture, politics and other unique factors. The Nation Brand Hexagon applies.

\subsubsection{The Nation Brand Hexagon}

Formulated by Simon Anholt (2000), the Nation Brand Hexagon (NBH) (Figure 3) is an assessment framework utilised to distinguish the distinct spheres of the nation brand. For the purposes of this model the NBH was adopted as the framework to outline the distinct components that make up a nation brand. The NBH is universally accepted as a model utilised in the assessment and practice of nation branding.

Figure 3: The Nation Brand Hexagon (NBH)

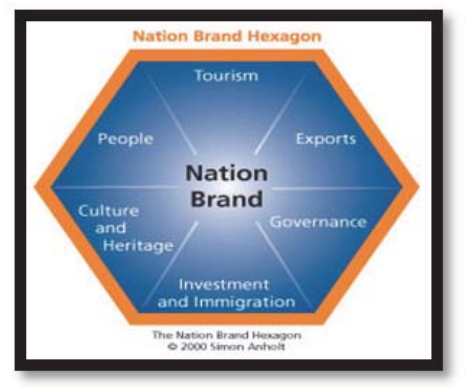

Source: Anholt (2000) on GfK North America Custom Research (2000).

The Nation Brand Hexagon outlines the distinct elements that make up the nation brand, as illustrated in Figure 3. This model premises that investors interact with a particular nation brand through one or multiple elements in the NBH, thereby forming an image or perception of the nation based on that interaction. It is important to note that the nation brand can be a combination of all six elements, or the utilisation of one core element in conjunction with other elements, or a completely one dimensional brand in some cases.

The elements of the NBH are briefly described by Kalamova and Konrad (2009) as:

- Tourism: the nation's attractiveness from a tourism point of view.

- Exports: the perceptions and stereotypes about products that originate from that nation.

- Governance: the perceptions that exist with regards to the government in a particular nation.

- Investment and Immigration: the personal willingness of foreigners to work in a particular nation and their perceptions about social and economic environment in that nation.

- People: stereotypes about people from that nation in general and as employees.

- Culture: perceptions about a nation's achievements in terms of culture, history and sports.

With particular reference to the Nation Brand Based Investment Promotion Model, one can suggest that the Nation Brand Hexagon elements can be utilised by a nation in the development of a nation brand as follows:

- Tourism: The use of natural and man-made tourism attractions to build a positive and distinct image of a nation and attract tourists. This is a common form of branding [referred to as Destination Branding] by smaller 
Island and African nations such as Mauritius and countries such as Kenya and Egypt which are heavily dependent on tourism income.

- Exports: Producer nations such as Japan and Germany often use their most well-known branded products to build their nation images. Japan prides itself on its reputation for producing high quality electronics (Canon, JVC, Epson), while Germany is world-renowned for its quality and ingenuity in luxury vehicle production (Mercedes Benz and BMW). Branded products build on Country-of-Origin advantages and this advantage spilled over, can be utilised to build a nation brand.

- Governance: The structure and style of government can also be a touch-point for nations in nation branding. One thinks of nations such as Switzerland, the proverbial 'neutral' state or the United States of America, a global beacon of democracy and an economic superpower. The aspect of governance in nation branding originates from the field of public diplomacy. A nation can build on positive governance brand to brand itself in other economic and non-economic spheres.

- Investment and Immigration: The nation brand can also be based on a nation's comparative or competitive advantage, as an investment or immigration destination. Investment hubs such as India can build their nation brand on their ability to attract investors, as an emerging economy with high return on investment potential. This investment potential can also be used to brand itself in other spheres such as tourism, and exports in terms of business and leisure tourism, and market, resource, strategic-asset and efficiency-seeking investment opportunities.

- Culture and Heritage: A nation's distinct culture and/or heritage can also be a nation brand touch point. Nations such as China and Israel hold particular reverence globally, for their unique cultures and heritages respectively. Israel is important to the Christian faith, and can build on its heritage to, for instance, boost cultural/religious tourism or attract immigrants.

- People: The people of a particular nation can also form a touch point as a nation brand. An example is the negative image that Nigeria has, as a result of its people being generally perceived to be corrupt and criminal. In this instance the Nigerian nation brand is adversely affected by the people of that country.

The second step during the phase 1 of the design of the Nation Brand Based Investment Promotion Model would be the specific focus and development of an investmentt destination brand for the nation. This phase would take into account the analytical model for the determinants and outcomes of Nation Branding by Sun (2009), which posits that the nation brand is a moderator within the decision making process of stakeholders such as foreign investors in cases where nations compete for resources such as investment funds based on almost similar comparative advantages. In essence, the nation brand in the proposed investment promotion model assumes the role of a positioning tool that symbolises and communicates a nation's unique combination of the cultural, economic, political, geographic and infrastructural factors considered by investors during the foreign direct investment decision-making process

The model was developed by Sun (2009) for in a study that attempted to model, test and explore: "Whether a nation's culture, economy, infrastructure, politics, reputable brands, reputable industries, and geographies, as determinants of the nation brand, have significant impact on its economic outcomes, as measured by exports, foreign direct investment, and tourism."

The following model (Figure 4), illustrates the relationship between the factors of comparative advantage, and the outcomes related to a nation having particular comparative advantages. The outcomes in this model include superior FDI inflows into a country, which are moderated by the nation brand, which is the focus of this model, as a potential tool for investment promotion for an African nation, to boost FDI inflows.

Figure 4: Analytical model for the determinants and outcomes of Nation Branding

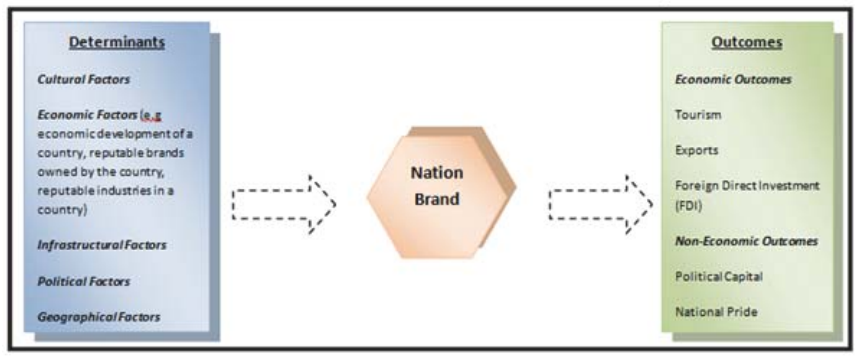

Source: Adapted from Sun (2009:4) 
Sun (2009) based the analytical model for the determinants and outcomes of nation branding, on the resource advantage theory, by Hunt and Morgan (1995), which according to Sun (2009), would better explain the phenomenon of firm diversity, particularly the out-performance of market-based economies over command economies. The justification offered by Sun (2009) for basing the model on the resource advantage theory, is how the theory, according to Hunt and Morgan (1995), illustrates how rewards flow to efficient and effective markets, due to their resource advantages. Sun (2009) goes on to cite Barney (1991) who ascertain that to have comparative advantage, firms have to implement value creating strategies, that are unique to the market and not being utilised by existing or potential competitors. The resource advantage theory is premised on the sustainable comparative advantage of firms. The comparative advantage of a firm results from the superior financial performance by those firms (Sun, 2009).

The question then becomes whether, it is possible to apply the resource advantage theory to nations? In his study, Sun (2009) argues that nations can indeed be considered as larger and more advanced forms of organisations, with many more stakeholders. An illustration of this argument is how for decades, nations have used their comparative advantage in tourism, to attract more visitors to their countries, and in export sales promotion by using Country-of-Origin (COO) as a branding strategy and establishing Export Processing Zones (EPZ's), to attract new market and efficiencyseeking investors to their nations. More specifically, comparative advantage is achieved by nations branding themselves, to achieve distinctive images in the highly competitive global market (Kaneva, 2011). This view of nations behaving as corporate entities is espoused by Haigh (2012) who believes that; "nations can adopt similar techniques [to products and corporations] to capitalize on the economic growth that comes with proper positioning of a nation brand. All nations should be working to actively realize such potential." As with firms in the resource advantage theory, nations must also consider the determining factors in the conception, execution and management of their symbolic meaning to their stakeholders. The following are some of the findings of the study by Sun (2009), based on this model:

- There is a positive and statistically significant relationship between, communication infrastructure, and industry factors in the attraction of FDI. "Countries with better communication infrastructure attracted more foreign direct investment, than those with inferior communication infrastructure." (Sun, 2009).

- "In a case where two countries have similar commercial resources, the country with the better image attracted more foreign travellers than the country with a poor image." (Sun, 2009).

- Country images have varying degrees of influence on the relationship between determinants and outcome factors of nation branding (Sun, 2009).

- "A country's existing nation image could interact with individual factors, or resources, to either positively or negatively influence the country's exports and tourism" (Sun, 2009).

With specific reference to the Nation Brand Based Investment Promotion Model, as a potential investment promotion approach, Sun's (2009) conceptual model is relevant as it takes into account the factors of comparative advantage, especially the factors that affect, amongst others, investor decisions when investment destinations are being considered. The model is also relevant in that it pivots the nation brand, as a moderator between the factors of comparative advantage, and the anticipated outcomes which include superior attraction power of FDI to a nation.

This implies that in a case where a nation is competing with other nations for investment and the determinants are almost similar; offset each other in relation to its competitors; or are unique to that nation, The nation brand becomes the critical touch point, with its target audience [investors], and the nation's image becomes the key seminal factor, of its ability to attract foreign investors. In other words, the symbolic meaning of the nation brand, to the target audience, has also become a source of enhancing competitive advantage, as branding only affects the customers' perception and does not alter the product (Fan, 2006).

\subsection{Phase 2: Communicators Of Nation Brand Identity}

Once a nation has established its distinct nation and investment brand respectively, the next step would be to communicate the nation's investment destination brand effectively through a customised investment promotion mix which is primarily based on the generic marketing promotion mix. In this model's investment promotion mix the generic mix elements of public relations, personal selling, advertising and sales promotion are used in conjunction with the principle communicators of nation-brand identity which include branded exports, tourist attractions and experiences, brand ambassadors and government foreign policy amongst others.

The Chartered Institute of Marketing (CIM) describes the promotion and the promotion mix as a set of tools that a business can use to effectively communicate the benefits of its products or services to its customers. The premise of the promotion mix in investment promotion is that if investors are not aware of the products and services a country provides 
then that nation is unable to compete in the global market-place. The implementation of an appropriate investment promotion mix will stimulate investors to invest in a country and the country can manage this within a budget it can afford.

The investment promotion mix essentially communicates the investment destination brand to investors through appropriate channels and at a cost that is sustainable to the nation. The traditional promotion mix is made up of the following elements, personal selling, advertising, public relations, sales promotion and direct marketing (CIM, 2009). However, in the context of the proposed model direct marketing falls away and the model outlines the investment promotion mix in relation to the four remaining elements.

\subsubsection{Advertising}

Advertising is paid for communication through the media (television, newspapers, trade magazines and journals and online). Advertising is defined by Brassington and Pettitt (2000) as any paid form of non-personal communication directed towards target audiences and transmitted through various mass media with the aim of promoting and presenting a product, service or idea. The aim of advertising for a country is to provide investors with information (create awareness of country as an investment destination brand); persuading investors to invest in the country (by promoting country's investment brand benefits); and reinforcing the existence of the country/nation in a positive light (by consistently repeating key nation brand messages). Elements in nation brand communication that apply to advertising are marketing communications and tourism experience.

\subsubsection{Public Relations}

Public relationsis what 'happens' to a country (positive or negative) and represents a sustained attempt to develop the country's reputation as an investment destination through non-paid media coverage. Brassington and Pettitt (2000) describe public relations as the activities that in nature seek to maintain a cordial relationship between an organisation and its various publics. Public relations would help to create a desirable image of a particular nation/country by keeping the nation brand in the investors' mind's eye. Tools of public relations include news and press releases to launch brandrelated programs with informative materials being distributed to journals or newspapers for their consideration and publication. In nation branding communication elements such as government foreign policy and sporting achievements are examples of tools to generate publicity.

\subsubsection{Sales Promotion}

Sales promotion according to the CIM (2009) is a short-term activity aimed at primarily attracting new customers. According to Brassington and Pettitt (2000) sales promotion is a combination of different tactical marketing techniques with mostly short-term incentives designed to add value in order to achieve specific sales and marketing objectives. Although sales promotion is not likely to build customer loyalty or long-term consumption decisions, investment sales promotion in the form of short-term tax incentives for instance, can motivate an investor to invest or at the very least consider investing in a particular country.

\subsubsection{Personal Selling}

The CIM (2009) considers personal selling to be the most effective form of promotion as it allows a tailored approach to the needs of specific investors. Personal selling is referred to by Brassington and Pettitt (2000) as a reciprocal communication tool between a representative of an organisation [country] and an individual or group. In the context of the proposed model personal selling intends to inform, persuade or remind investors of a nation's investment brand, the nation's investment benefits and the nation as an attractive investment destination respectively. Personal selling is an effective form of relationship management and the individuals selected to facilitate and manage these investor relations and represent nation as a brand have the potential to make or break the nation as an investment destination. Elements in nation branding for personal selling include prominent personalities such as the president and sports persons and the nation's diaspora.

\subsection{Phase 3: Nation-Brand Image Formation}

The final step in the investment promotion model is the nation-brand image formation stage. This is probably the most 
important stage of the model where the nation must strategically and effectively target the relevant audience with its nation investment brand. The model identifies domestic consumers, external consumers, domestic firms, external firms, inward investors, governments and the media as key stakeholders, with the model particularly focusing on these stakeholders as being paramount to the targeting and attraction of market-seeking, resource-seeking, efficiency-seeking and strategic-asset seeking investors to a nation. The phases two and three are highly subjective and are uniquely dependant on individual nations in terms of their formulation and application.

\subsection{Nation Brand Image}

The final stage of the proposed model is the targeting of the audiences relevant to the country in terms of foreign direct investment. Unlike in mainstream marketing practice, the nation brandare formulated for a wider audience with no particular target investor in mind given the tremendous costs that would be involved in targeted marketing programs. As Haigh (2012) suggests, "developing the investment segment of a nation brand allows a country to attract greater foreign direct investment (FDI) as well as increase the interest of investors in opportunities within a country." That is to say the focus of the model would be to create interest in the country as a whole by developing a multi-spectral umbrella brand that attracts interests, creates desire within and prompts action from foreign investors respectively.

With this in mind and according to Proksch (2003) the proposed model identifies four distinct types of foreign direct investors that nations can target:,

1. Resources-seeking Investors - this type of investor specifically relates to seeking to extract, and/or exploit resources from the investment destination. This type of investment is not normally preferred as an investment type by developing nations, since resource-seeking investment has limited benefits for the host country and its development.

2. Market-seeking Investors - in this case the investor seeks to exploit market opportunities within the host country. Most developing nations welcome such FDI as if yields employment, which increases income generation, hence boosting a nation's commerce.

3. Efficiency-seeking Investors -this type of investor primarily seeks to utilize the competitive advantages inherent in a particular location. This may be for production, input acquisition, value addition or finishing of products.

4. Strategic asset-seeking Investors - this type of investor often seeks mergers and acquisitions to establish a global presence. In developing countries, it often means the uptake of struggling state enterprises in key infrastructure development and management (power generation, railway management) by foreign investors.

\section{Discussion and Conclusion}

This paper has posited a theoretical framework that seeks to establish a relationship between nation branding and investment promotion in the African context. It is imperative that individual African nations take stock of their images and actively seek to manage them for the overall enhancement of their ability to compete with other 'developed' nations. Collectively, individual nation re-imaging programs would ultimately contribute to 'enlightening' the 'Dark Continent 'to the rest of the world. More importantly proactive image management as posited by this paper would positively influence the inflow of much needed foreign direct investment to African tourist facilities, sustainable natural resource exploitation and key civil construction facilities. Gaps in perception between the brand identity of a nation (what is projected by the country) and the existing brand image of the nation (the country as perceived by the rest of the world) exist, and nation branding is an approach that can be utilised to bridge that gap. As Wells and Wint (2000) conclude, in some cases investors may have an unfavourable image of a country, be it a true reflection of that country or not, impacting on the ultimate investment decision. To this effect they strongly recommended that nations seek to correct their unfavourable images, before attempting to generate investment, particularly because, investors must have some prior interest in a potential investment destination (Wells and Wint 2000).

Nation branding, has increasingly evolved into a tool that can be harnessed to contribute to the development of African economies. This will be realized through the management of a nation's image and perceptions thereof, in the minds of its key stakeholders, such as investors. At a time of finite financial resources and increased nation-based competition, the image of a nation can be considered to be a key element of competitive advantage. Western governments such as those of France, the United States of America, Germany and England (Dinnie, 2008) seem to have grasped the concept of image management and its inherent advantages to their economies and it is the purpose of this paper to challenge African nations to follow suit, as have South Africa Dinnie (2008) and Kenya in the recent past Brand 
Kenya Board (2013).

The Nation Brand Based Investment Promotion Model (NBBIPM) offers African nations a methodology to harness traditional marketing and branding techniques in the creation and management of an investment destination brand which would enhance the marketing of investment opportunities and continuously attract inward investment. The NBBIPM offers a template for the re-imaging of a nation and outlines an integrated marketing communication approach towards the projection of an attractive investment destination brand image, while taking into account the key aspect of nation branding, which is that there is no one-size fits all strategy to nation branding. This aspect contributed to the dynamic nature of this generic model, which can be tailor-suited to meet the image management requirements of any nation for investment promotion purposes. It is our hope that this model contributes to the process of the development of distinct African nation brands or at the very least enable governments to critically consider the key elements in nation-image driven investment promotion strategies going forward.

\section{References}

Anholt, S. (2000). The Nation Brand Index. GfK North America Custom Research. [Online] Available:http://www.gfjamerica.com/practice_areas /roper_pam/nbi_index/index.en.html. (September 14, 2012).

Avraham, E \& Ketter, E. Media strategies for marketing places in crisisimproving the image of cities, countries and tourist destinations.(Oxford: ButterworthHeinemann).

Bellosso, J.C. (2008). Country brand. A differentiation mechanism and source of intangibles. Paradigmes, Issue No 5 (October 2010), pp44-51.

Brassington, F. and Pettitt, S. (2000) Principles of marketing, $2^{\text {nd }}$ edition. Harlow: Pearson Education Limited.

Chartered Institute of Marketing (2009). How to achieve an effective promotional. [Online] Available: mix.www.cim.co.uk/marketingresources. (January 15, 2013).

Darley, W.K. (2012). Increasing Sub-Saharan Africa's share of foreign direct investment and public policy challenges, strategies, and implications. Journal of African Business, 13(1), pp 62-69

De Best, Maya. (2010). Who shapes the image of the Netherlands? An analysis of the stakeholders that influence the image of a country' Master's Thesis. Erasmus University, Rotterdam. Faculty of history and Art. [Online] Available: oaithesis.eur.nl/ir/repub/asset/8061/Thesis_mdebest final20100820.pdf., (April 13, 2011).

Dinnie K. (2008). Nation Branding: Concepts, Issues, Practice.Oxford: Butterworth-Heinemann.

Duah, Agyeman, Rachel. P. (2010). Nation branding as a tool for the increase of foreign direct investment.Dissertation BSc Business Administration. Ashesi University College. Ghana.

Fan. Y. (2009). Branding the Nation: Towards a Better Understanding. Brunel University [Online] Available:www.bura.brunel.ac.uk/.../NB\%20Towards\%20a \%20better\%20understanding.pdf, (March 6, 2010).

Grundey, Dianora, Tolub, B \& Brukiene, J. (2006). Country image as a marketing tool for fostering innovation and entrepreneurship. Kaumas Faculty of Humanities. Vilnius University. Lithuania.

Haigh, D. (2012). Foreword. Brand Finance Journal. Special Nation Brands Issue: August 2012. pp 2

Kalamova, Magarita. M and Konrad, K.A. (2010). Nation Brands and Foreign Direct Investment Research Paper. Max-Planck-Institute for Intellectual Property Rights, Competition and Tax Law. Berlin: The Social Science Research Centre.

Kaneva Nadia. (2011). Nation Branding: Toward an Agenda for Critical Research.' International Journal of Communications, 5(2011). pp117-141.

Martin, M. Ingrid and Sevgin Eroglu (1993). Measuring a Multi-Dimensional Construct: Country Image, Journal of Business Research, 28 (3), 191-2 10.

Matiza, T \& Oni, O.A (2013). Nation branding as a strategic marketing approach to foreign direct investment promotion: The case of Zimbabwe. Mediterranean Journal of Social Sciences, MCSER Publishing: Rome, 4(13), pp475-488.

Morisset, J. (2001). Foreign direct investment in Africa: Policies also matter. New Horizons and policy challenges for foreign direct investment in the 21st Century. OECD Global Forum on International Investment.

Odenthal, L \& Zimny, Z (1999). Foreign direct investment in Africa: Performance and potential. United Nations Conference on Trade and Development (UNCTAD). UNTCAD/ITE/IIT/MISC.15.

Organisation for Economic Co-operation and Development (OECD). (2010). Policy framework for investment toolkit. Investment promotion and facilitation. The Investment Division of the OECD Directorate of Financial and Enterprises Affairs.

Partzalis, J, Roderiguez, C.A. (2002). Country names and brands: Symbolic meaning and capital flows. [Online] Available: www.sba.muohio.edu/abas/1999/pantzajo.pdf, (March 13, 2010).

Proksch .M. (2003). Investment promotion and enterprise development bulletin for Asia and the Pacific No 2. United Nations Publications. Sale No E.04.II.F.9.

Sichei MM \& Kinyondo G . (2012). Determinants of FDI in Africa: A panel data analysis. Global Journal of Management and Business Research, 12(18), pp 84-97.

Sun, Q. (2009). An Analytical Model of the Determinants and Outcomes of Nation Branding. Doctor of Philosophy Dissertation (Marketing. University of North Texas. USA.)

Trnik, M. (2007). The role of investment promotion agencies at attracting foreign direct investment and their impact on economic development in Central Europe. (The Czech Republic and Slovakia in comparative perspective). Master of Arts Dissertation, international relations and European Studies, Central European University, Budapest, Hungary.

United Nations (1995). Reviving Investment in Africa: Constraints and policies. Economic Commission for Africa: Ethiopia.

United Nations Industrial Development Organisation (UNIDO), (2011). Africa Investor Report 2011-Towards evidence-based Investment Promotion Strategies. ISBN: 978-92-1-1-106450-6.

Wells, L, T and Wint, A, G. (2000). Marketing a country: Promotion as a tool for attracting foreign investment. Revised Edition. Foreign Investment Advisory Service. Occasional Paper 13. [Online] Available: www.rru.worldbank.org/Documents/PapersLinks/244.pdf, (May 8, 2010). 